\title{
Comparison of Volatile Organic Compound Concentrations in Ambient Air among Different Source Areas around Khon Kaen, Thailand
}

\author{
Pornpun Sakunkoo 1,2, Saksit Phonphinyo ${ }^{1}$, Naowarat Maneenin 2,3, Chananya Jirapornkul 2,3, \\ Yuparat Limmongkon ${ }^{1,2, *}$, Jetnapis Rayubkul ${ }^{2,4}$, Sakesun Thongtip ${ }^{5,6}$ and Sarawut Sangkham ${ }^{5, * \mathbb{D}}$
}

check for updates

Citation: Sakunkoo, P.; Phonphinyo, S.; Maneenin, N.; Jirapornkul, C.; Limmongkon, Y.; Rayubkul, J.; Thongtip, S.; Sangkham, S. Comparison of Volatile Organic Compound Concentrations in Ambient Air among Different Source Areas around Khon Kaen, Thailand Atmosphere 2021, 12, 1694. https:// doi.org/10.3390/atmos12121694

Academic Editor: Stéphane Le Calvé

Received: 22 October 2021

Accepted: 16 December 2021

Published: 17 December 2021

Publisher's Note: MDPI stays neutral with regard to jurisdictional claims in published maps and institutional affiliations.

Copyright: (c) 2021 by the authors. Licensee MDPI, Basel, Switzerland. This article is an open access article distributed under the terms and conditions of the Creative Commons Attribution (CC BY) license (https:// creativecommons.org/licenses/by/ $4.0 /)$.
1 Department of Environmental Health Occupational Health and Safety, Faculty of Public Health, Khon Kaen University, Muang District, Khon Kaen 40002, Thailand; spornp@kku.ac.th (P.S.); saksit.pholpinyo@gmail.com (S.P.)

2 Occupational Health Safety and Environmental Epidemiology Group (OHSEE), Faculty of Public Health, Khon Kaen University, Muang District, Khon Kaen 40002, Thailand; naowtu@kku.ac.th (N.M.); chananya@kku.ac.th (C.J.); jetray@kku.ac.th (J.R.)

3 Department of Epidemiology and Biostatistics, Faculty of Public Health, Khon Kaen University, Muang District, Khon Kaen 40002, Thailand

4 Faculty of Public Health, Khon Kaen University, Muang District, Khon Kaen 40002, Thailand

5 Department of Environmental Health, School of Public Health, University of Phayao, Muang District, Phayao 56000, Thailand; sake_115@hotmail.com

6 Atmospheric Chemistry and Climate Model Laboratory, Atmospheric Pollution and Climate Change Research Unit, University of Phayao, Muang District, Phayao 56000, Thailand

* $\quad$ Correspondence: yupali@kku.ac.th (Y.L.); sarawut.sa@up.ac.th (S.S.)

\begin{abstract}
Volatile organic compounds (VOCs) are a complex group of chemicals that pose a direct risk to human health. They also lead to the formation of other air pollution constituents, including fine particulate matter $\left(\mathrm{PM}_{2.5}\right)$ and ground level ozone $\left(\mathrm{O}_{3}\right)$. The ambient air concentrations of 19 VOCs were measured using multi-day $24 \mathrm{~h}$ sampling at two urban sites and two rural sites in the area of Khon Kaen, Thailand. Results showed that most VOCs were at concentrations considered acceptable according to the $24 \mathrm{~h}$ average standards established by the Thai Pollution Control Department. The VOC acrolein, however, was detected at concentrations $\left(0.69-1.15 \mu \mathrm{g} / \mathrm{m}^{3}\right)$ in excess of the $24 \mathrm{~h}$ average standard $\left(0.55 \mu \mathrm{g} / \mathrm{m}^{3}\right)$. Two other VOCs, benzene and 1,3-butadiene, were also detected at elevated levels (1.73-2.75 and $0.18-0.40 \mu \mathrm{g} / \mathrm{m}^{3}$, respectively) that indicated the potential to exceed the 1-year average standard. VOC concentrations were highest in the urban market monitoring site, suggesting that vehicle exhaust and food preparation using cooking oil at high temperatures may have been potential sources of the elevated VOCs.
\end{abstract}

Keywords: acrolein; aerosols; air pollution; human health; ozone

\section{Introduction}

Across Southeast Asia, air pollution is a major health problem, estimated to contribute to $5-12 \%$ of the total burden of disease, as measured by disability-adjusted life years (DALYs) in the region [1]. Although fine particulate matter $\left(\mathrm{PM}_{2.5}\right)$ pollution has received notable attention in Thailand [2,3], less attention has been dedicated to volatile organic compounds (VOCs). VOCs, however, are both a health threat themselves and important precursors to $\mathrm{PM}_{2.5}$ and ground-level ozone $\left(\mathrm{O}_{3}\right)$ [4,5]. Legislation passed in 2007 initiated VOC monitoring as part of routine air pollution monitoring in Thailand; however, to date, VOC monitoring remains limited in much of Thailand [6], with only a subset of VOCs measured at specific air monitoring sites.

Monitoring VOCs is important because VOCs negatively impact human health via multiple pathways. First, VOCs can undergo photochemical reactions with nitrogen oxides 
$\left(\mathrm{NO}_{\mathrm{x}}\right)$ and ultraviolet (UV) radiation to produce ground-level $\mathrm{O}_{3}$ [7]. Exposure to groundlevel $\mathrm{O}_{3}$ has been associated with decreased lung function [8] and pre-term births [9]. Secondly, VOCs emitted from biogenic and anthropogenic sources can react to form secondary organic aerosols (SOAs) [10,11], which contribute to $\mathrm{PM}_{2.5}$ and smog [12,13]. Exposure to $\mathrm{PM}_{2.5}$ has been linked with increased mortality, cardiovascular disease, respiratory disease, and increased hospitalizations [14,15]. Thirdly, direct exposure to VOCs affects human health. Exposure to VOCs, such as benzene, toluene, ethylbenzene, and xylenes, results in cellular toxicity across the nervous and respiratory systems [16,17]. Therefore, VOCs represent a complex and critical environmental pollution threat.

Northeast Thailand has several important sources of VOCs. Vehicle exhaust represents a significant source of VOC emissions in urban areas [18,19]. In particular, the incomplete combustion of motorbikes, which are a popular mode of transportation in the area, can create high ambient concentrations of VOCs [20]. Outside of urban areas, the sources of VOCs are different. Biogenic sources of VOCs, such as vegetation and biomass burning, are substantial, especially in the tropics [21]. Other anthropogenic sources typically located outside urban areas in Thailand include industrial activities and power generation [22]. These problems caused by VOCs and other air pollutants are amplified during the winter months (December to March), as chronic temperature inversions trap ground-level air pollution in the region [23].

Therefore, the purpose of this study was to characterize VOC concentrations in and around Khon Kaen, Thailand, which is the primary city of northeast Thailand. A group of 19 VOCs was monitored over multiple days in December 2020, using three sites representative of different VOC sources, including one site in the vicinity of an urban market, an electronics manufacturing site, and a biomass power plant. Results were used to compare relative sources of VOCs and identify VOCs of primary concern in northeast Thailand.

\section{Materials and Methods}

\subsection{Monitoring Sites}

Four sites located around Khon Kaen, Thailand were used for monitoring VOCs. The first two sites were located inside the urban center of Khon Kaen (Figure 1). The first urban site (Khon Kaen Monitoring Station in the Water Resource Regional Office: MK1) is the air pollution monitoring station operated by the Pollution Control Department. The second urban site (urban market site: MK2) was located near an important daily market with high levels of traffic, especially from motorbikes. The other two sites were located outside the urban center but near potential VOC sources. One site (rural industrial site: MK3) was located near an electronics industrial site, whereas the other site (rural power generation site: MK4) was located near a biomass power generation station.

\subsection{Air Sampling and Analysis}

Evacuated canisters purged with nitrogen and equipped with flow control valves were used to collect $24 \mathrm{~h}$ samples at three of the sites (urban market, rural industrial site, and rural power generation site). At each site, sampling was conducted on three different days throughout December 2020. At the end of the $24 \mathrm{~h}$ sampling period, the flow control valve was closed, and the samples were transported to the laboratory for analysis with a gas chromatography-flame ionization detector [24,25]. A total of 19 VOC species were analyzed in the samples. Data were obtained from the fourth site (Khon Kaen Monitoring Station), which is operated by the Pollution Control Department. VOC data were collected there using VOC detectors (sub-atmospheric pressure sampling canisters). This data included concentrations for 16 VOC species. [25]. For example, VOC studies of different air sampling collection methods and VOC analysis techniques are listed in Table 1. 


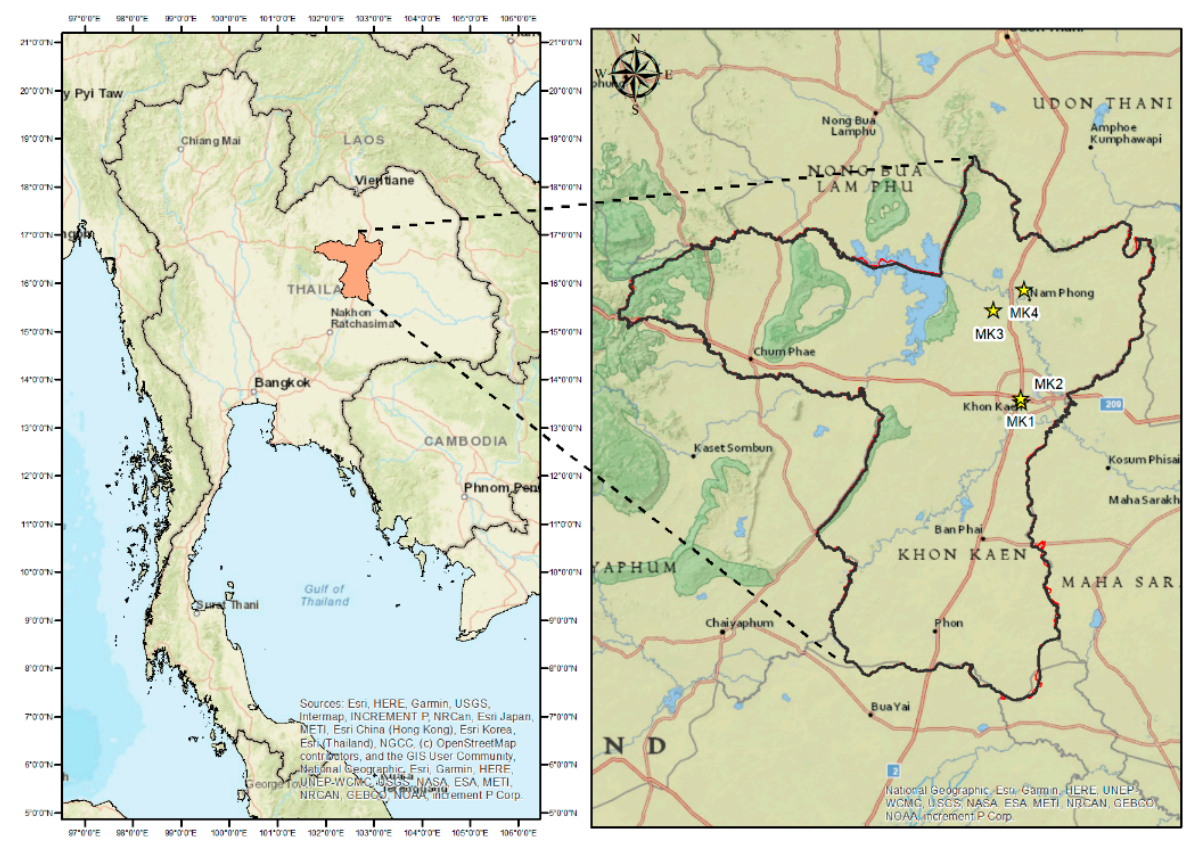

Figure 1. Map of the study area: four sites located around Khon Kaen Province shown via satellite imagery; the area around the Hydrology Division of the Water Resources Regional Office 4 (MK1), the area in front of Banglumpoo Market (MK2), the area in front of a rural industrial site (MK3), and the area around a rural power generation site (MK4).

Table 1. Selected Country Comparison of VOCs in the Ambient Air Studies Method.

\begin{tabular}{|c|c|c|c|c|c|c|}
\hline Continent & Country & Sampling Site & $\begin{array}{l}\text { Ambient } \\
\text { Collection } \\
\text { Methods }\end{array}$ & $\begin{array}{l}\text { Techniques of } \\
\text { VOC Analyzer } \\
\text { Used }\end{array}$ & $\begin{array}{l}\text { Number of } \\
\text { Measured } \\
\text { VOC }\end{array}$ & Reference \\
\hline \multirow[t]{6}{*}{ Asia } & Malaysia & Urban & $\begin{array}{c}\text { Tedlar air sampling } \\
\text { bags with an } \\
\text { air pump }\end{array}$ & GC-MS & 17 & [24] \\
\hline & Beijing, China & Urban & - & $\begin{array}{l}\text { Airmo VOC online } \\
\text { analyzer (GC-866) }\end{array}$ & 59 & [26] \\
\hline & Hangzhou, China & Urban & $\begin{array}{l}\text { Silica SUMMA } \\
\text { canisters }\end{array}$ & GC-MS & 107 & [27] \\
\hline & Dezhou, China & Rural & $\begin{array}{l}\text { Stainless steel } \\
\text { canisters }\end{array}$ & GC-MSD/FID & 58 & [28] \\
\hline & Tokyo & Urban & $\begin{array}{l}\text { Fused-silica-lined } \\
\text { canister }\end{array}$ & GC-MS & 18 & [29] \\
\hline & $\begin{array}{l}\text { Khon Kaen, } \\
\text { Thailand }\end{array}$ & Urban + Rural & $\begin{array}{c}\text { Passive canister } \\
\text { sampler }\end{array}$ & GC-FID & 19 & This study \\
\hline Europe & London, UK & Urban & - & GC-MS & 54 & [30] \\
\hline North America & Los Angeles, USA & Urban & - & PTR-MS, GC-MS & 26 & [31] \\
\hline
\end{tabular}

\subsection{Data Analysis and Quality Control}

Samples were transferred from the canister to a preconcentration unit which concentrated - and at the same time minimized — the sample volume to be injected into a gas chromatography-flame ionization detector; the measurement techniques used are based on the US EPA method [25]. The average and range for each VOC were computed at each site by compiling the data from the three sampling days. These values were then compared against the applicable $24 \mathrm{~h}$ ambient air quality standards established by Thailand's Pollution Control Department. 


\section{Results and Discussion}

\subsection{VOC Concentrations in Ambient Air}

Overall, the concentrations of VOCs were similar among the monitored areas, suggesting these values are representative of regional ambient air quality. However, some VOC constituents were higher in the urban market site compared to the two rural areas (Table 2). Specifically, acetaldehyde, benzene, 1,3-butadiene, and acrolein (2-propenal) were found in higher concentrations at the urban market site compared to the two industrial sites. On the other hand, several VOC constituents were below detection levels across all sites, including benzyl chloride, 1,2-dibromoethane, 1,4-dichlorobenzene, tetrachloroethylene, 1,1,2,2-tetrachloroethane, and trichloroethylene. VOCs emitted from an urban source to the atmosphere may cause pollution on a local scale. In the urban and industrial areas, VOC emissions could result from the industrial source and anthropogenic activities and also be affected by traffic sources; in particular, emissions from motor vehicles were the dominant source of VOC in the urban area [32], and vehicle exhaust emissions (35.59 percent gasoline exhaust, 9.93 percent diesel exhaust) were a major contributor, accounting for 45.52 percent of total VOCs [26]. Meanwhile, the lowest levels of $\mathrm{VOC}$ and $\mathrm{NO}_{2}$ occurred during summer, owing to the increase in solar radiation and lower traffic densities [33].

Table 2. Average of the $24 \mathrm{~h}$ concentrations of VOCs in ambient air $(n=3)$.

\begin{tabular}{|c|c|c|c|c|}
\hline Pollutant & $\begin{array}{c}\text { Khon Kaen } \\
\text { Monitoring Station }\end{array}$ & Urban Market & Rural Industrial & $\begin{array}{c}\text { Rural Power } \\
\text { Generation }\end{array}$ \\
\hline Acetaldehyde & NM & 12.30 & 7.79 & 11.07 \\
\hline Acrylonitrile & ND & $<0.22$ & $<0.22$ & ND \\
\hline Benzene & 1.2 & 2.75 & 1.85 & 1.73 \\
\hline Benzyl chloride & ND & ND & ND & ND \\
\hline 1,3-Butadiene & ND & 0.40 & 0.18 & 0.18 \\
\hline Bromomethane & ND & 0.54 & 0.47 & 0.54 \\
\hline Carbon tetrachloride & 0.19 & $<0.31$ & $<0.31$ & $<0.31$ \\
\hline Chloroform & 0.05 & $<0.24$ & $<0.24$ & ND \\
\hline 1,2-Dibromoethane & ND & ND & ND & ND \\
\hline 1,4-Dichlorobenzene & ND & ND & ND & ND \\
\hline 1,2-Dichloroethane & 0.22 & 0.24 & 0.24 & 0.24 \\
\hline Dichloromethane & 1.10 & 0.49 & 0.49 & 0.42 \\
\hline 1,2-Dichloropropane & ND & 0.28 & 0.46 & $<0.23$ \\
\hline 1,4-Dioxane & NM & ND & $<0.36$ & ND \\
\hline 2-Propenal/acrolein & NM & 1.15 & 0.82 & 0.69 \\
\hline Tetrachloroethylene & ND & ND & ND & ND \\
\hline 1,1,2,2-Tetrachloroethane & ND & ND & ND & ND \\
\hline Trichloroethylene & ND & ND & ND & ND \\
\hline Vinyl chloride & ND & $<0.13$ & $<0.13$ & ND \\
\hline
\end{tabular}

$\mathrm{ND}=$ Not detected. The level of detection was $0.04-0.20 \mu \mathrm{g} / \mathrm{m}^{3}$, depending on the parameter. $\mathrm{NM}=$ Not measured. If "<" is shown, it means the parameter was detected but at a concentration less than the level of quantification, which is reported in the table.

The results indicated that most VOCs were found at concentrations acceptable according to local ambient air quality standards. However, one VOC (acrolein) was detected at concentrations in excess of the $24 \mathrm{~h}$ average standard. Additionally, two other VOCs (benzene and 1,3-butadiene) were detected at concentrations that would exceed the 1-year average standard and should, therefore, be carefully monitored. The results also indicated that these VOCs were detected in higher concentrations at the urban market site relative to the rural monitoring sites, suggesting urban sources. It is important to consider the human health risks associated with exposure to VOCs, as well as the potential for the VOCs to contribute to ground level $\mathrm{O}_{3}$. In particularly, benzene, toluene, ethyl benzene and xylene (BTEX) have been found to be some of the most common forms of VOCs linked to cancer risk in tropical cities [33]. Moreover, there is carcinogenic and non-carcinogenic risk via inhalation exposure to VOCs [34]. Therefore, the observed values were compared against 
$24 \mathrm{~h}$ and 1-year average standards for ambient air quality established by the Pollution Control Department. Two VOC constituents were found throughout the monitoring period to have an average concentration in excess of the 1-year average standard in at least one site, namely benzene and 1,3-butadiene (Table 3). Because this study collected ambient air samples throughout the month of December and were collected under typical conditions, it is expected that the actual 1-year average concentrations would not deviate substantially from these values. Therefore, these VOC constituents should be prioritized for further monitoring. The 3-day average concentration of benzene exceeded the 1-year average standard at three of four monitored sites, whereas the average concentration for 1,3-butadiene exceeded the 1-year average standard at only one site (the urban market).

Table 3. Summary of the ambient air standards established by the Pollution Control Department applicable to a $24 \mathrm{~h}$ average and 1-year average $\left(\mu \mathrm{g} / \mathrm{m}^{3}\right)$.

\begin{tabular}{|c|c|c|c|}
\hline Pollutant & $\begin{array}{c}24 \mathrm{~h} \text { Average } \\
\text { Standard }\left(\mu \mathrm{g} / \mathrm{m}^{3}\right)\end{array}$ & $\begin{array}{c}\text { 1-Year Average } \\
\text { Standard }\left(\mu \mathrm{g} / \mathrm{m}^{3}\right)\end{array}$ & Exceeded $^{1}$ \\
\hline Acetaldehyde & 860 & $\mathrm{n} / \mathrm{a}$ & \\
\hline Acrylonitrile & 10 & $\mathrm{n} / \mathrm{a}$ & \\
\hline Benzene & 7.6 & 1.7 & * \\
\hline Benzyl chloride & 12 & $\mathrm{n} / \mathrm{a}$ & \\
\hline 1,3-Butadiene & 5.3 & 0.33 & * \\
\hline Bromomethane & 190 & $\mathrm{n} / \mathrm{a}$ & \\
\hline Carbon tetrachloride & 150 & $\mathrm{n} / \mathrm{a}$ & \\
\hline Chloroform & 57 & 0.43 & \\
\hline 1,2-Dibromoethane & 370 & $\mathrm{n} / \mathrm{a}$ & \\
\hline 1,4-Dichlorobenzene & 1100 & $\mathrm{n} / \mathrm{a}$ & \\
\hline 1,2-Dichloroethane & 48 & 0.4 & \\
\hline Dichloromethane & 210 & 22 & \\
\hline 1,2-Dichloropropane & 82 & 4 & \\
\hline 1,4-Dioxane & 860 & $\mathrm{n} / \mathrm{a}$ & \\
\hline 2-Propenal/acrolein & 0.55 & $\mathrm{n} / \mathrm{a}$ & $* *$ \\
\hline Tetrachloroethylene & 400 & 200 & \\
\hline 1,1,2,2-Tetrachloroethane & 83 & $\mathrm{n} / \mathrm{a}$ & \\
\hline Trichloroethylene & 130 & 23 & \\
\hline Vinyl chloride & 20 & 10 & \\
\hline
\end{tabular}

Additionally, the average concentration of acrolein exceeded the $24 \mathrm{~h}$ average standard at all three sites for which data were available. Because these values were $24 \mathrm{~h}$ averages that met the definition of the standard, the concentrations of acrolein failed the ambient air quality standards at all three sites for which data were available.

\subsection{Selected Country of Comparison with Other Studies Performed in Asia}

VOC concentrations are generally measured in urban and rural areas, as shown in Table 4. Air sampling methodologies and VOC analysis procedures vary because VOCs are organic compounds depending on each nation's technology and setting. Several VOC species can have different chemical properties. VOC research is primarily undertaken in cities [35], and short-period VOC studies are more common than year-long studies. Furthermore, the available VOC species in the calibration standards control the VOCs detected in each investigation. As a result, the VOC concentrations reported in various investigations must be interpreted with caution [35]. For example, aromatic hydrocarbons (e.g., solvents toluene, benzene, ethylbenzene, xylenes, styrene, and phenol) which come from various sources such as the environment, waste combustion, and paints can be found in both urban and rural areas of human activities, as shown in this study and other studies in selected countries from Asia. Recently, the contributions of VOCs to secondary organic 
aerosols (SOAs) formation potential are also highest for aromatic hydrocarbons with a value of 94 percent, followed by alkanes and alkene. Among these, the contributions of toluene and benzene add up to over 70 per cent in Shenyang, China [36]. These results showed that benzene in the ambient air in Muang Khon Kaen, which is derived mainly from vehicle exhaust gases [37], is significantly related to traffic and industrial sources [36]. This interpretation is consistent with previous studies [37-43]. According to the study, evaporative emissions account for roughly $4 \%$ (varying from 1-15\%) of total (1,3-butadiene) emissions from Australian motor vehicles (exhaust and evaporative) [42]. Additionally, it was indicated that traffic emissions accounted for $28.9 \%$ of total volatile organic carbon, followed by combustion, industrial, gasoline volatilization, and solvent at $24.7 \%, 21.3 \%$, $12.4 \%$, and $11.7 \%$, respectively [34]. The selected country of concentration of VOC studies in Asia is shown in Table 4.

The study of the concentration of VOCs measured at four locations in Muang Khon Kean found that the highest concentration of benzene in $24 \mathrm{~h}$ in the urban market was $2.75 \mu \mathrm{g} / \mathrm{m}^{3}$, followed by rural industrial, rural power generation, and Khon Kaen Monitoring at 1.85, 1.73 , and $1.20 \mu \mathrm{g} / \mathrm{m}^{3}$, respectively. From Table 4, it can be observed that concentrations of VOCs were found at the urban and other different environmental conditions. Our study is consistent with other studies [24,26] that detected benzene in ambient air in urban, industrial, and residential areas [32]. Some VOCs can directly affect human health (e.g., benzene), while others contribute to the formation of ozone and aerosol particles in the atmosphere [44]. For example, benzene is a known carcinogen, and exposure to high ambient concentrations represents a considerable health risk [45]. The World Health Organization (WHO) has estimated that a lifetime exposure of $1 \mu \mathrm{g} / \mathrm{m}^{3}$ benzene through inhalation leads to about six additional cases of leukemia per million inhabitants [46]. Therefore, we need to further assess the health risks associated with VOC exposure, especially carcinogenic compounds.

\subsection{Comparison with Other Studies Performed in Other Continents}

Table 5 provides some information about the VOC concentration studies. The study of the seasonal variation of biogenic and anthropogenic VOCs in a semi-urban area near Sydney, Australia, found an average concentration of approximately $0.4 \mathrm{ppb}$, with a slight decrease during autumn-winter [47]. In our study, ambient air samples were collected during winter. The result showed that concentrations of most VOCs are below the standard in $24 \mathrm{~h}$ of PCD Thailand, except for 2-propenal/acrolein. Consistent with the Sydney study, Australia was found to be influenced by domestic, commercial and vehicle anthropogenic volatile organic carbon (AVOC) [47]. Generally, $\mathrm{VOC}$ and $\mathrm{NO}_{2}$ concentrations were higher in winter and autumn than in spring and summer. Hence, VOC and $\mathrm{NO}_{2}$ levels reach a maximum in the winter due to higher atmosphere stability, and a minimum in summer, when atmosphere dispersion is more important [32]. According to a study conducted on the level of VOCs in the ambient air of a medium-sized city in northern Spain, VOC concentrations are higher in winter than in summer, as illustrated in Table 4 . The average concentrations of benzene, toluene, ethylbenzene, xylenes, propylbenzene, and tri-methylbenzenes were $2.84,13.26,2.15,6.01,0.59$ and $1.32 \mu \mathrm{g} / \mathrm{m}^{3}$ [32]. A previous study highlighted that VOC concentrations in Los Angeles, California decreased by more than two orders of magnitude at an annual rate of approximately $7.5 \%$ over the previous five years [31]. Toronto, Canada, has reported a reduction of up to $40 \%$ in VOC reactivity [48]. Currently, the trend in VOC levels is decreasing due to the enforcement of emission reduction measures, demonstrating the effectiveness of strategies adopted to date for improving air quality in urban areas [45]. Due to a tighter and earlier emission reduction policy, the VOC trend in Los Angeles decreased earlier than in London [45]. However, VOCs are still detectable in heavily industrialized countries with petrochemicals and heavy-traffic cities, or areas of open waste-burning or combustion of hazardous waste [49]. 
Table 4. Selected Country Comparison of VOC Concentrations in Ambient Air in Asia.

\begin{tabular}{|c|c|c|c|c|c|c|c|}
\hline $\begin{array}{c}\text { Kuala Lumpur, } \\
\text { Malaysia } \\
\text { [24] }\end{array}$ & 24-h Average (ppbv) ${ }^{a}$ & $\begin{array}{c}\text { Beijing, China } \\
{[26]}\end{array}$ & $\begin{array}{c}\text { 24-h Average } \\
\left(\mu \mathrm{g} / \mathrm{m}^{3}\right)^{\mathrm{b}}\end{array}$ & $\begin{array}{c}\text { Bangkok, } \\
\text { Thailand } \\
\text { [37] }\end{array}$ & $\begin{array}{c}\text { 24-h Average } \\
\left(\mu \mathrm{g} / \mathrm{m}^{3}\right)^{\mathrm{c}}\end{array}$ & $\begin{array}{c}\text { Yokohama, } \\
\text { Japan } \\
{[43]}\end{array}$ & $\begin{array}{l}\text { 24-h Average } \\
\left(\mu \mathrm{g} / \mathrm{m}^{3}\right)^{d}\end{array}$ \\
\hline Methylene chloride & $295 \pm 267$ & Acetylene & $3.91 \pm 2.65$ & Benzene & $8.8^{c} / 3.9^{d}$ & Benzene & $2.1 \pm 2.7^{\mathrm{I}} / 0.7 \pm 0.6^{\mathrm{C}}$ \\
\hline 1,2,4-Trimethylbenzene & $169 \pm 103$ & Benzene & $4.18 \pm 2.17$ & 1,3-Butadiene & $0.51^{\mathrm{c}} / 0.17^{\mathrm{d}}$ & Toluene & $5.2 \pm 5.7^{\mathrm{I}} / 2.2 \pm 1.4^{\mathrm{C}}$ \\
\hline Toluene & $153 \pm 83.2$ & Toluene & $3.17 \pm 2.62$ & Chloroform & $0.16^{\mathrm{c}} / 0.15^{\mathrm{d}}$ & Ethylbenzene & $2.9 \pm 3.7^{\mathrm{I}} / 0.5 \pm 0.3^{\mathrm{C}}$ \\
\hline Methyl methacrylate & $96.5 \pm 69.0$ & Ethylbenzene & $0.56 \pm 0.54$ & Dichloromethane & $1.4^{\mathrm{c}} / 2.6^{\mathrm{d}}$ & $m, p$-Xylene & $2.1 \pm 2.3^{\mathrm{I}} / 0.6 \pm 0.4^{\mathrm{C}}$ \\
\hline Allyl chloride & $74.3 \pm 134$ & Styrene & $0.62 \pm 0.60$ & 1,2-Dichloropropane & $0.21^{c} / 0.16^{d}$ & m-Ethyltoluene & $0.2 \pm 0.1^{\mathrm{I}} / 0.2 \pm 0.1^{\mathrm{C}}$ \\
\hline n-Butylbenzene & $54.6 \pm 82.9$ & o-Xylene & $0.01 \pm 0.02$ & Tetrachloroethylene & $0.25^{c} / 0.18^{d}$ & p-Ethyltoluene & $0.2 \pm 0.1^{\mathrm{I}} / 0.2 \pm 0.1^{\mathrm{C}}$ \\
\hline Styrene & $51.8 \pm 57.6$ & i-Propylbenzene & $0.01 \pm 0.01$ & Trichloroethylene & $0.37^{\mathrm{c}} / 0.41^{\mathrm{d}}$ & o-ethyltoluene & $0.1 \pm 0.1^{\mathrm{I}} / 0.1 \pm 0.1^{\mathrm{C}}$ \\
\hline p-Xylene & $49.4 \pm 29.0$ & n-Propylbenzene & $0.34 \pm 0.30$ & Vinyl chloride & $0.41^{\mathrm{c}} / 0.18^{\mathrm{d}}$ & 1,3,5-Trimethylbenzene & $0.1 \pm 0.1^{\mathrm{I}} / 0.1 \pm 0.1^{\mathrm{C}}$ \\
\hline 1,3-Dichlorobenzene & $40.5 \pm 53.4$ & m-Ethyltoluene & $0.04 \pm 0.05$ & & & 1,2,4-Trimethylbenzene & $0.3 \pm 0.3^{\mathrm{I}} / 0.3 \pm 0.2^{\mathrm{C}}$ \\
\hline Ethylbenzene & $39.8 \pm 39.3$ & p-Ethyltoluene & $0.09 \pm 0.13$ & & & Trichloroethylene & $0.1 \pm 0.1^{\mathrm{I}} / 0.1 \pm 0.1^{\mathrm{C}}$ \\
\hline Benzene & $21.0 \pm 15.3$ & o-ethyltoluene & $0.11 \pm 0.12$ & & & p-Dichlorobenzene & $0.1 \pm 0.1^{\mathrm{I}} / 0.1 \pm 0.1^{\mathrm{C}}$ \\
\hline $\begin{array}{c}\text { 1-Chloro-2- } \\
\text { methylbenzene }\end{array}$ & $20.3 \pm 32.2$ & 1,2,4-Trimethylbenzene & $0.38 \pm 0.34$ & & & & \\
\hline 1,4-Dichlorobenzene & $19.0 \pm 41.4$ & 1,2,3-Trimethylbenzene & $0.08 \pm 0.05$ & & & & \\
\hline 2-Chlorotoluene & $5.1 \pm 10.0$ & m-Diethylbenzene & $0.02 \pm 0.05$ & & & & \\
\hline sec-Butylbenzene & $3.2 \pm 3.3$ & $\begin{array}{l}\text { p-Diethylbenzene } \\
\text { Naphtalene }\end{array}$ & $\begin{array}{l}0.03 \pm 0.05 \\
0.00 \pm 0.00\end{array}$ & & & & \\
\hline
\end{tabular}

${ }^{a}$ Urban. ${ }^{b}$ Urban + Haze days. ${ }^{c}$ Urban + Roadside. ${ }^{d}$ Urban/Residential-(Industrial (I) in Shiohama site)/(Commercial (C) in Sakuragicho site). 
Table 5. Selected Country Comparison of VOC Concentrations in Ambient Air in Other Continents.

\begin{tabular}{|c|c|c|c|c|c|}
\hline $\begin{array}{c}\text { Rome, Italy } \\
{[45]}\end{array}$ & Average $\left(\mu \mathrm{g} / \mathrm{m}^{3}\right)^{a}$ & $\begin{array}{c}\text { Cyprus } \\
\text { [50] }\end{array}$ & $\begin{array}{l}24 \mathrm{~h} \text { Average } \\
\left(\mu \mathrm{g} / \mathrm{m}^{3}\right)^{\mathrm{b}}\end{array}$ & $\begin{array}{c}\text { Spain } \\
\text { [32] }\end{array}$ & $\begin{array}{l}24 \mathrm{~h} \text { Average } \\
\left(\mu \mathrm{g} / \mathrm{m}^{3}\right)^{\mathrm{c}}\end{array}$ \\
\hline Benzene & $3.29 \pm 1.61$ & Ethane & 3.05 & Benzene & $1.33 \pm 0.38^{\mathrm{s}} / 1.82 \pm 1.59^{\mathrm{w}}$ \\
\hline Toluene & $10.58 \pm 8.58$ & Ethylene & 0.35 & Toluene & $8.74 \pm 3.20^{\mathrm{s}} / 12.02 \pm 2.73^{\mathrm{w}}$ \\
\hline Ethyl benzene & $0.43 \pm 0.37$ & Propane & 2.20 & Tetrachloroethene & $0.43 \pm 0.21^{\mathrm{s}} / 0.45 \pm 0.16^{\mathrm{w}}$ \\
\hline$m, p$-Xylene & $6.03 \pm 5.04$ & Propene & 0.19 & Ethylbenzene & $1.30 \pm 0.44^{\mathrm{s}} / 1.69 \pm 0.50^{\mathrm{w}}$ \\
\hline o-Xylene & $0.56 \pm 0.49$ & i-Butane & 0.32 & $m, p$-Xylene & $2.47 \pm 0.95^{\mathrm{s}} / 2.65 \pm 0.64^{\mathrm{w}}$ \\
\hline 1,3,5-Trimethylbenzene & $0.44 \pm 0.41$ & n-Butane & 0.54 & o-Xylene & $1.71 \pm 0.60^{\mathrm{s}} / 1.52 \pm 0.29^{\mathrm{w}}$ \\
\hline \multirow[t]{11}{*}{ 1,2,4-Trimethylbenzene } & $0.25 \pm 0.22$ & Acetylene & 0.71 & i-Propylbenzene & $0.19 \pm 0.05^{\mathrm{s}} / 1.01 \pm 0.93^{\mathrm{w}}$ \\
\hline & & i-Pentane & 0.25 & Bromobenzene & $10.96 \pm 2.68^{\mathrm{s}} / 1.91 \pm 2.15^{\mathrm{w}}$ \\
\hline & & n-Pentane & 0.21 & Propylbenzene & $0.23 \pm 0.07^{\mathrm{s}} / 0.73 \pm 0.35^{\mathrm{w}}$ \\
\hline & & Benzene & 0.37 & 1,3,5-Trimethylbenzene & $1.67 \pm 0.25^{\mathrm{s}} / 1.04 \pm 0.54^{\mathrm{w}}$ \\
\hline & & Toluene & 0.19 & Naphtalene & $0.18 \pm 0.15^{\mathrm{s}} / 0.11 \pm 0.02^{\mathrm{w}}$ \\
\hline & & Isoprene & 0.13 & & \\
\hline & & $\alpha$-Pinene & 0.33 & & \\
\hline & & $\beta$-Pinene & 0.34 & & \\
\hline & & Monoterpenes & 1.34 & & \\
\hline & & Methanol & 3.84 & & \\
\hline & & $\begin{array}{l}\text { Acetaldehyde } \\
\text { Acetone }\end{array}$ & $\begin{array}{l}0.83 \\
2.72\end{array}$ & & \\
\hline
\end{tabular}

${ }^{a}$ Urban air + Winter. ${ }^{b}$ Urban (Cyprus Atmospheric Observatory). ${ }^{c}$ Summer (s) + Winter (w).

This study demonstrated that acrolein exceeded ambient air quality standards to the greatest degree. Acrolein is a highly reactive carbonyl found in both indoor and outdoor air [51]. It has been associated with cardiovascular disease, asthma, and lung cancer [52]. It can come from a variety of sources, including off-gassing from plastics and woods [53] and cigarettes [54]. However, two very important sources of acrolein are the volatilization of cooking oils and motor vehicle exhaust [55]. Indoor air concentrations of acrolein have been shown to have a diurnal pattern highly associated with cooking patterns in the household [56]. The half-life of acrolein from cooking events has been measured at $14 \mathrm{~h}$, making air exchange an important factor to reduce exposure [57]. Preparing food with cooking oil at high temperatures is common in Thai cooking, especially in urban markets. Additionally, the market's proximity to streets and vehicle exhausts likely constituted an additional source of acrolein and benzene. Furthermore, 1,3-butadiene, which was also detected at higher levels at the urban market site, will generate acrolein as a result of photooxidation [58]. Collectively, these results suggest that cooking and vehicle exhaust may have contributed to unacceptably high levels of VOCs in the urban market.

A limitation to this study is the challenges associated with the analytical methods for VOCs. Acrolein is particularly difficult to quantify analytically due to its extremely high volatility [59]. Therefore, the results should be confirmed with additional analytical methods, such as proton-transfer-reaction mass spectrometry or derivatization with other compounds. Furthermore, this study did not account for seasonal or diurnal variability in VOC concentrations. It is important to consider the contribution of diurnal variations in the photoreactivity of VOCs to ozone and other SOAs [45]. Therefore, although these results point to the need to prioritize certain VOCs, that priority may vary with changes in meteorological and economic conditions. 


\section{Conclusions}

This study measured key VOCs across urban and rural sites in northeastern Thailand. The concentrations of carbonyl acrolein were in excess of the $24 \mathrm{~h}$ average standard established by the Thai Pollution Control Department. The concentrations of acrolein and the associated VOCs benzene and 1,3-butadiene were higher in the urban market monitoring site relative to the rural monitoring sites. These results suggested that the presence of vehicle exhaust and food preparation using cooking oil at high temperatures may be the sources of VOCs in the urban market. Further VOC monitoring should prioritize acrolein, benzene, and 1,3-butadiene in northeast Thailand with efforts made to identify their sources and quantify exposure levels.

Author Contributions: Conceptualization, P.S. and S.S.; methodology, P.S. and S.P.; validation, P.S. and S.P.; formal analysis, S.P.; investigation, P.S. and S.P.; data curation, S.P.; writing-original draft preparation, S.S. and P.S.; writing-review and editing, P.S., N.M., C.J., Y.L., J.R., S.T. and S.S.; visualization, S.S.; funding acquisition, P.S. All authors have read and agreed to the published version of the manuscript.

Funding: This research was funded by research program funding from Khon Kaen University, [Grant number: RP64006].

Institutional Review Board Statement: Not applicable.

Data Availability Statement: Not applicable.

Acknowledgments: We gratefully appreciate the coordination and access provided by the industrial and power generation companies, as well as by the Mueang Khon Kaen Police Station, in order to collect the air samples. We also sincerely thank Thanawut Norat at the Regional Environmental Office, Region 10 for providing secondary data. In addition, we are thankful to the Occupational Health Safety and Environmental Epidemiology Group (OHSEE) for statistical counseling. We are also grateful to Patipat Vongruang, a specialist in geographic information systems (GIS), who provided design maps of the monitoring site in this study. We would like to thank Anthony Kuster for helping with English proofreading and editing.

Conflicts of Interest: The authors declare no conflict of interest.

\section{References}

1. Murray, C.J.L.; Aravkin, A.Y.; Zheng, P.; Abbafati, C.; Abbas, K.M.; Abbasi-Kangevari, M.; Abd-Allah, F.; Abdelalim, A.; Abdollahi, M.; Abdollahpour, I.; et al. Global Burden of 87 Risk Factors in 204 Countries and Territories, 1990-2019: A Systematic Analysis for the Global Burden of Disease Study 2019. Lancet 2020, 396, 1223-1249. [CrossRef]

2. Fold, N.R.; Allison, M.R.; Wood, B.C.; Thao, P.T.B.; Bonnet, S.; Garivait, S.; Kamens, R.; Pengjan, S. An Assessment of Annual Mortality Attributable to Ambient $\mathrm{PM}_{2.5}$ in Bangkok, Thailand. Int. J. Environ. Res. Public Health 2020, 17, 7298. [CrossRef] [PubMed]

3. ChooChuay, C.; Pongpiachan, S.; Tipmanee, D.; Suttinun, O.; Deelaman, W.; Wang, Q.; Xing, L.; Li, G.; Han, Y.; Palakun, J.; et al. Impacts of $\mathrm{PM}_{2.5}$ Sources on Variations in Particulate Chemical Compounds in Ambient Air of Bangkok, Thailand. Atmos. Pollut. Res. 2020, 11, 1657-1667. [CrossRef]

4. Xiang, S.; Liu, J.; Tao, W.; Yi, K.; Xu, J.; Hu, X.; Liu, H.; Wang, Y.; Zhang, Y.; Yang, H.; et al. Control of Both $\mathrm{PM}_{2.5}$ and $\mathrm{O}_{3}$ in Beijing-Tianjin-Hebei and the Surrounding Areas. Atmos. Environ. 2020, 224, 117259. [CrossRef]

5. Xue, L.K.; Wang, T.; Gao, J.; Ding, A.J.; Zhou, X.H.; Blake, D.R.; Wang, X.F.; Saunders, S.M.; Fan, S.J.; Zuo, H.C.; et al. Ground-Level Ozone in Four Chinese Cities: Precursors, Regional Transport and Heterogeneous Processes. Atmos. Chem. Phys. 2014, 14, 13175-13188. [CrossRef]

6. Tunsaringkarn, T.; Prueksasit, T.; Morknoy, D.; Semathong, S.; Rungsiyothin, A.; Zapaung, K. Seasonal and Spatial Variation of Ambient Air Volatile Organic Compounds in Pathumwan District, Bangkok, Thailand. J. Health Res. 2015, 29, $135-142$.

7. Algrim, L.B.; Ziemann, P.J. Effect of the Hydroxyl Group on Yields and Composition of Organic Aerosol Formed from OH Radical-Initiated Reactions of Alcohols in the Presence of NOx. ACS Earth Space Chem. 2019, 3, 413-423. [CrossRef]

8. Holm, S.M.; Balmes, J.R. Systematic Review of Ozone Effects on Human Lung Function, 2013 through 2020. CHEST 2021. [CrossRef] [PubMed]

9. Rappazzo, K.M.; Nichols, J.L.; Rice, R.B.; Luben, T.J. Ozone Exposure during Early Pregnancy and Preterm Birth: A Systematic Review and Meta-Analysis. Environ. Res. 2021, 198, 111317. [CrossRef]

10. Sillman, S. The Relation between Ozone, NOx and Hydrocarbons in Urban and Polluted Rural Environments. Atmos. Environ. 1999, 33, 1821-1845. [CrossRef] 
11. Jimenez, J.L.; Canagaratna, M.R.; Donahue, N.M.; Prevot, A.S.H.; Zhang, Q.; Kroll, J.H.; DeCarlo, P.F.; Allan, J.D.; Coe, H.; $\mathrm{Ng}$, N.L.; et al. Evolution of Organic Aerosols in the Atmosphere. Science 2009, 326, 1525-1529. [CrossRef]

12. Lonati, G.; Giugliano, M.; Butelli, P.; Romele, L.; Tardivo, R. Major Chemical Components of PM 2.5 in Milan (Italy). Atmos. Environ. 2005, 39, 1925-1934. [CrossRef]

13. Turap, Y.; Rekefu, S.; Wang, G.; Talifu, D.; Gao, B.; Aierken, T.; Hao, S.; Wang, X.; Tursun, Y.; Maihemuti, M.; et al. Chemical Characteristics and Source Apportionment of $\mathrm{PM}_{2.5}$ during Winter in the Southern Part of Urumqi, China. Aerosol Air Qual. Res. 2019, 19, 1325-1337. [CrossRef]

14. Lu, F.; Xu, D.; Cheng, Y.; Dong, S.; Guo, C.; Jiang, X.; Zheng, X. Systematic Review and Meta-Analysis of the Adverse Health Effects of Ambient PM 2.5 and PM10 Pollution in the Chinese Population. Environ. Res. 2015, 136, 196-204. [CrossRef] [PubMed]

15. Li, Z.; Wen, Q.; Zhang, R. Sources, Health Effects and Control Strategies of Indoor Fine Particulate Matter (PM 2.5$)$ : A Review. Sci. Total Environ. 2017, 586, 610-622. [CrossRef] [PubMed]

16. Bolden, A.L.; Kwiatkowski, C.F.; Colborn, T. New Look at BTEX: Are Ambient Levels a Problem? Environ. Sci. Technol. 2015, 49, 5261-5276. [CrossRef]

17. Montero-Montoya, R.; López-Vargas, R.; Arellano-Aguilar, O. Volatile Organic Compounds in Air: Sources, Distribution, Exposure and Associated Illnesses in Children. Ann. Glob. Health 2018, 84, 225-238. [CrossRef] [PubMed]

18. Hui, L.; Liu, X.; Tan, Q.; Feng, M.; An, J.; Qu, Y.; Zhang, Y.; Deng, Y.; Zhai, R.; Wang, Z. VOC Characteristics, Chemical Reactivity and Sources in Urban Wuhan, Central China. Atmos. Environ. 2020, 224, 117340. [CrossRef]

19. Fakkaew, N.; Bualert, S.; Thongyen, T.; Rungratanaubon, T. Ozone Formation Potential of Ambient Volatile Organic Compounds at Roadside in Bangkok, Thailand. Appl. Environ. Res. 2021, 43, 14-28. [CrossRef]

20. Lin, Y.-C.; Chou, F.-C.; Li, Y.-C.; Jhang, S.-R.; Shangdiar, S. Effect of Air Pollutants and Toxic Emissions from Various Mileage of Motorcycles and Aerosol Related Carcinogenicity and Mutagenicity Assessment. J. Hazard. Mater. 2019, 365, 771-777. [CrossRef]

21. Sahu, L.K.; Tripathi, N.; Yadav, R. Contribution of Biogenic and Photochemical Sources to Ambient VOCs during Winter to Summer Transition at a Semi-Arid Urban Site in India. Environ. Pollut. 2017, 229, 595-606. [CrossRef]

22. Zheng, C.; Shen, J.; Zhang, Y.; Zhu, X.; Wu, X.; Chen, L.; Gao, X. Atmospheric Emission Characteristics and Control Policies of Anthropogenic VOCs from Industrial Sources in Yangtze River Delta Region, China. Aerosol Air Qual. Res. 2017, 17, $2263-2275$. [CrossRef]

23. Kliengchuay, W.; Worakhunpiset, S.; Limpanont, Y.; Meeyai, A.C.; Tantrakarnapa, K. Influence of the Meteorological Conditions and Some Pollutants on PM10 Concentrations in Lamphun, Thailand. J. Environ. Health Sci. Eng. 2021, 19, 237-249. [CrossRef]

24. Hosaini, P.-N.; Khan, M.-F.; Musstaffa, I.-H.; Amil, N.; Mohamad, N.; Jaafar, S.-A.; Nadzir, S.-M.; Latif, M.-T. Concentration and source apportionment of volatile organic compounds (VOCs) in the ambient air of Kuala Lumpur, Malaysia. Nat. Hazards 2017, 85, 437-452. [CrossRef]

25. Pollution Control Department(PCD), Ministry of Natural Resource and Environment. Development of Environmental and Emission Standards of Volatile Organis Compounds (VOCs) in Thailand. Available online: http://infofile.pcd.go.th/air/Report_ VOCs.pdf (accessed on 18 October 2021).

26. Zhang, L.; Wang, X.; Li, H.; Cheng, N.; Zhang, Y.; Zhang, K.; Li, L. Variations in levels and sources of atmospheric VOCs during the continuous haze and non-haze episodes in the urban area of Beijing: A case study in spring of 2019. Atmoshere 2021, 12, 171. [CrossRef]

27. Han, L.; Chen, L.; Li, K.; Boa, Z.; Zhao, Y.; Zhang, X.; Azzi, M.; Cen, K. Source apportionment of volatile organic compounds (VOCs) during ozone polluted day in Hangzhou, China. Atmoshere 2019, 10, 780. [CrossRef]

28. Zhu, Y.; Yang, L.; Chen, J.; Wang, X.; Xue, L.; Sui, X.; Wen, L.; Xu, C.; Yao, L.; Zhang, J.; et al. Characteristics of ambient volatile organic componds and the influence of biomass burning at a ruaral site in North China during summer 2013. Atmos. Environ. 2016, 124, 156-165. [CrossRef]

29. Hoshi, J.; Amano, S.; Sasaki, Y.; Korenaga, T. Investigation and estimation of emission sources of 54 volatile organic compounds in ambient air in Tokyo. Atmos. Environ. 2008, 42, 2383-2393. [CrossRef]

30. von Schneidemesser, E.; Monk, P.S.; Plass-Duelmer, C. Global comparison of VOC and CO observation in urban areas. Atmos. Environ. 2010, 44, 5053-5064. [CrossRef]

31. Warneke, C.; De Gouw, J.A.; Holloway, J.S.; Peischl, J.; Ryerson, T.B.; Atlas, E.; Blake, D.; Trainer, M.; Parrish, D.D. Multiyear trends in volatile organic compounds in Los Angeles, California: Five decades of decreasing emissions. J. Geophys. Res. Atmos. 2012, 117, 1-10. [CrossRef]

32. Parra, M.A.; Elustondo, D.; Bermejo, R.; Santamaría, J.M. Ambient air levels of volatile organic compounds (VOC) and nitrogen dioxide (NO2) in a medium size city in Northern Spain. Sci. Total Environ. 2009, 407, 999-1009. [CrossRef] [PubMed]

33. Limi Hanif, N.-M.; Hawari, S.S.; Othman, M.; Abd Hamid, H.-H.; Ahamad, F.; Uning, R.; Gee Ooi, M.-C.; Wahab, I.-A.; Sahani, M.; Latif, M.-T. Ambient volatile organic compounds in tropical environments: Potential sources, composition and impacts-A review. Chemosphere 2021, 285, 131355. [CrossRef] [PubMed]

34. Xuan, L.; Ma, Y.; Xing, Y.; Meng, Q.; Song, J.; Chen, T.; Wang, H.; Wang, P.; Zhang, Y.; Gao, P. Source, temporal variation and health risk of volatile organic compounds (VOCs) from urban traffic in harbin, China. Environ. Pollut. 2021, 270, 116074. [CrossRef]

35. Mozaffar, A.; Zhang, Y.-L. Atmoshere volatile organic compounds (VOCs) in China: A Review. Curren Pollut. Rep. 2020, 6, 250-263. [CrossRef] 
36. Liu, N.; Li, X.; Ren, W.; Li, L.; Su, C.; Wang, C. Concentration Characteristics and Photochemical Reactivities of VOCs in Shenyang, China. Atmosphere 2021, 12, 1240. [CrossRef]

37. Laowagul, W.; Yoshizumi, K. Characteristics of volatile organic compounds with Enforcement of Thai Air Quality Standard in Bankkok, Thailand. Seikatsu Eisei (J. Urban Living Health Assoc.) 2009, 1, 19-32. [CrossRef]

38. Duffy, B.L.; Nelson, P.F.; Ye, Y.; Weeks, I.A.; Galbally, I.E. Emissions of benzene, toluene, xylene and 1,3-butadiene from a representative portion of the Australian car fleet. Atmos. Environ. 1998, 32, 2693-2704. [CrossRef]

39. Batterman, S.; Hatzivasilis, G.; Jia, C. Concentrations and emissions of gasoline and other vapors from residential vehicle garages. Atmos. Environ. 2006, 40, 1828-1844. [CrossRef]

40. Han, X.; Naeher, L.P. A review of traffic-related air pollution exposure assessment studies in the developing world. Environ. Int. 2006, 32, 106-120. [CrossRef]

41. Na, K. Determination of VOC source signature of vehicle exhaust in a traffic tunnel. J. Environ. Manag. 2006, 81, 392-398. [CrossRef]

42. Ye, Y.; Galbally, I.E.; Weeks, I.A.; Duffy, B.L.; Nelson, P.F. Evaporation emissions of 1,3-butadiene from petro-fueled motor vehicles. Atmos. Environ. 1998, 32, 2685-2692. [CrossRef]

43. Tiwari, V.; Hanai, Y.; Masunaga, S. Ambient levels of voltile organic compounds in the vicinity of petrochemical industrial area of Yokohama, Japan. Air Qual. Atmos. Health 2010, 3, 65-75. [CrossRef] [PubMed]

44. Guan, Y.; Zhang, Y.; Zhang, Y.; Wang, X.; Han, J.; Song, W.; Hou, L.; Duan, E. Pollution Characteristics and key reactive species of volatile organic compounds in Beijing-Tianjin-Hebei area, China. Aerosol Air Qual. Res. 2020, 20, 1886-1897. [CrossRef]

45. Fanizza, C.; Incoronato, F.; Baiguera, S.; Schiro, R.; Brocco, D. Volatile organic compound levels at one site in Rome urban air. Atmos. Pollut. Res. 2014, 5, 304-314. [CrossRef]

46. World Health Organization (WHO). Air Quality Guidelines For Europe. Who Regional Publication. European Series; World Health Organization, Regional Office for Europe: Copenhagen, Denmark, 1999.

47. Ramirez-Gamboa, J.; Paton-Walsh, C.; Galbally, I.; Simmons, J.; Guerette, E.A.; Griffith, A.D.; Chambers, S.D.; Williams, A.G. Seasonal variation of biogenic and anthropogenic VOCs in a semi-urban area near Sydney, Australia. Atmosphere $2021,12,47$. [CrossRef]

48. Geddes, J.A.; Murphy, J.G.; Wang, D.K. Long term changes in nitrogen oxides and volatile organic compounds in Toronto and the challenges facing local ozone control. Atmos. Environ. 2009, 43, 3407-3415. [CrossRef]

49. Barabad, L.M.; Jung, W.; Versoza, M.E.; Lee, Y.I.; Choi, K.; Park, D. Characteristics of particulate matter and volatile organic compound emissions from the combustion of waste vinyl. Int. J. Environ. Res. Public Health 2018, 15, 1390. [CrossRef]

50. Debevec, C.; Sauvage, S.; Gros, V.; Sciare, J.; Pikridas, M.; Stavroulas, I. Origin and variability in volatile organic compounds observed at an Eastern Mediterranean background site (Cyprus). Atmosperic Chem. Phys. 2017, 17, 11355-11388. [CrossRef]

51. Ghilarducci, D.P.; Tjeerdema, R.S. Fate and Effects of Acrolein. In Reviews of Environmental Contamination and Toxicology: Continuation of Residue Reviews; Ware, G.W., Ed.; Springer: New York, NY, USA, 1995; pp. 95-146, ISBN 978-1-4612-2550-8.

52. Zirak, M.R.; Mehri, S.; Karimani, A.; Zeinali, M.; Hayes, A.W.; Karimi, G. Mechanisms behind the Atherothrombotic Effects of Acrolein, a Review. Food Chem. Toxicol. 2019, 129, 38-53. [CrossRef]

53. Schieweck, A. Very Volatile Organic Compounds (VVOC) as Emissions from Wooden Materials and in Indoor Air of New Prefabricated Wooden Houses. Build. Environ. 2021, 190, 107537. [CrossRef]

54. Ruprecht, A.A.; de Marco, C.; Saffari, A.; Pozzi, P.; Mazza, R.; Veronese, C.; Angellotti, G.; Munarini, E.; Ogliari, A.C.; Westerdahl, D.; et al. Environmental Pollution and Emission Factors of Electronic Cigarettes, Heat-Not-Burn Tobacco Products, and Conventional Cigarettes. Aerosol Sci. Technol. 2017, 51, 674-684. [CrossRef]

55. Destaillats, H.; Spaulding, R.S.; Charles, M.J. Ambient Air Measurement of Acrolein and Other Carbonyls at the Oakland-San Francisco Bay Bridge Toll Plaza. Environ. Sci. Technol. 2002, 36, 2227-2235. [CrossRef]

56. Seaman, V.Y.; Bennett, D.H.; Cahill, T.M. Origin, Occurrence, and Source Emission Rate of Acrolein in Residential Indoor Air. Environ. Sci. Technol. 2007, 41, 6940-6946. [CrossRef] [PubMed]

57. Seaman, V.Y.; Bennett, D.H.; Cahill, T.M. Indoor Acrolein Emission and Decay Rates Resulting from Domestic Cooking Events. Atmos. Environ. 2009, 43, 6199-6204. [CrossRef]

58. Liu, X.; Jeffries, H.E.; Sexton, K.G. Hydroxyl Radical and Ozone Initiated Photochemical Reactions of 1,3-Butadiene. Atmos. Environ. 1999, 33, 3005-3022. [CrossRef]

59. Schieweck, A.; Uhde, E.; Salthammer, T. Determination of Acrolein in Ambient Air and in the Atmosphere of Environmental Test Chambers. Environ. Sci. Process. Impacts 2021, 23, 1729-1746. [CrossRef] 